that the fat-body is not derived from the oenocytes, that it is not of ectodermal but of mesodermal origin as claimed by the majority of authors, and that there is no evidence for the origin of the blood from the oenocytes.

It is interesting to note that only the winged orders of Hexapoda, the Pterygota, seem to possess oenocytes. I could find no traces of these peculiar cells in Lepisma saccharina, Campodea fragilis (young and adult) and Anurida maritima, insects which may be taken to represent the three families of the Apterygota. If oenocytes exist at all in this subdivision of the Hexapoda, they are probably confined to the embryo or to the forms most closely allied to the Orthoptera - like Machilis.

I believe that oenocytes do not occur in the Myriopoda. In the just-born young of Scolopendra complanata from the Galapagos I find no traces of them and so far as I am aware they have not been described by any of the investigators of Myriopod anatomy.

\title{
DESCRIPTION OF A SARCOPHAGA BRED FROM HELIX.
}

BY C. H. TYLER TOWNSEND, LAS CRUCES, N. MEX.

I have recently received from $\mathrm{Mr}$. $\mathrm{H}$. A. Surface, of the Ohio experiment station, a small Sarcophagid which he bred from Helix thyroides Say, while engaged on his catalogue of shells of Franklin County, published in Bulletin 2 , volume I, technical series, of that station.

Mr. Surface accompanies the specimen with the following note: "The snail was placed in a tight bottle August 25, in Warren County, Ohio, and during the first part of September the pupae were seen. From September 27 to 30 five or six mature flies came forth."

The fly proves to be a small species of Sarcophaga. After considerable time spent in looking over descriptions of North American species, I feel justified in considering it new.

\author{
Sarcophaga helicis n. sp. $\quad$ ․
}

Eyes brown, bare; front, sides of face and cheeks silvery or cinereous, sometimes with a brassy reflection; frontal vitta dark brown or blackish, about one-third width of front, the front being about one-third width of head; frontal bristles descending a little below base of antennae; the two vertical bristles strongest, directed backward, next three bristles also directed backward, rest more or less forward; two orbital bristles directed forward; a strong anterior pair of ocellar bristles directed forward and outward; sides of face with a few bristles in a row on lower portion next orbital margin; cheeks about one-fourth eye-height, sparsely hairy with a row of bristles on lower border; facial depression more or less silvery, epistoma rather prominent; facial ridges bare except two or three bristly hairs next vibrissae, the latter decussate and inserted on the oral margin; antennae a little shorter than face, black, second joint slightly elongate with a long bristle on front border, third joint 
abont twice as long as second, moderately wide, rounded at apex; arista blackish, thickened on basal fourth, plumose on basal half, 3-jointed, second joint short; proboscis not so long as height of head, fleshy, dark brown or blackish, with well developed labella; palpi nearly black, moderately long, stout at tip, clothed with a few small bristles longest on the underside; occiput cinereous, clothed with black hairs and fringed with black bristles. Thorax cinereous, with three well defined black vittae reaching scutellum, and with moderately strong macrochaetae; scutellum cinereous, with an apical decussate pair of macrochaetae overreaching base of third abdominal segment, a shorter lateral pair, and a weak sub-discal pair. Abdomen black, more or less heavily shaded with silvery or cinereous, in some places with a golden shade, first segment not shortened; first segment without macrochaetae, second segment with a lateral one; third segment with a median marginal pair and a lateral pair, anal segment with a marginal row of six or eight macrochaetae; anus slightly rufous. Legs blackish, femora more or less cinereous especially front ones; tibiae more or less spiny, especially middle pair; claws and pulvilli short. Wings longer than abdomen, grayish hyaline, with very small costal spine, first vein spined half its length, second spined to small cross-vein; apical cell opening before tip of wing, fourth vein bent at right angle, with wrinkle at bend, apical cross-vein bowed in; hind cross-vein oblique, nearer to bend of fourth vein; tegulae nearly white, halteres blackish.

Length of body $5 \mathrm{~mm}$; of wing $4 \mathrm{~mm}$.

Described from one specimen. Ohio. Sept.

Edwards's N. A. Butterfles.

We seem among old friends in the twelfth part of Edwards's Butterflies of North Ameriica, which appeared early in January; for the early stages figured are of species, Papilio zolicaon and Chionobas uhleri, very similar to those whose histories have been before illustrated, while the additional figures of butterflies are of other forms of the same genera, $P$. americus and $C$. varuna. In both the species of which the life-history is told, there are interesting features. In P. zolicaon the spring butterflies are found to be from wintering chrysalids of all three of the broods of the previous season; it would be instructive to learn in what proportions the first and second broods are represented, and whether any of the chrysalids of the first brood disclose their inmates at the season of the third. In C. uhleri breeding and field observations together show the species to be in part double, in part single brooded, and the exact statistics given are very valuable, since the behavior of the species of this genus is very irregular and incongruous, and every new fact helps toward a solution of difficulties elsewhere. It is needless but pleasant to add that the same abundance, one might almost say luxury, of illustration is employed as heretofore, and it is of marvellous delicacy and truthfulness.

Mr. Edwards would render his plates simpler if instead of employing the letters of the alphabet for the different illustrations of the early stages, without uniformity, he would always use some specific and invariable designation, as I, II, or $l^{1}, l^{2}$, for the different larval stages. Any one can tell at a glance an egg from a caterpillar or a chrysalis, but when the earlier larval stages are magnified, it requires much comparison of letters with legend to ascertain which stage of the caterpillar is presented in particular cases; whereas if figures ( 1,2 , etc.) either by themselves or in connection with the letter $l$ were used, no such reference would be needed, and comparisons could be more readily made. It would also be simpler if in his text he would employ the terms "Ist stage," "2d stage," etc., or some equivalent term instead of "young larva," "after ist moult, etc., neither of which is really definite 

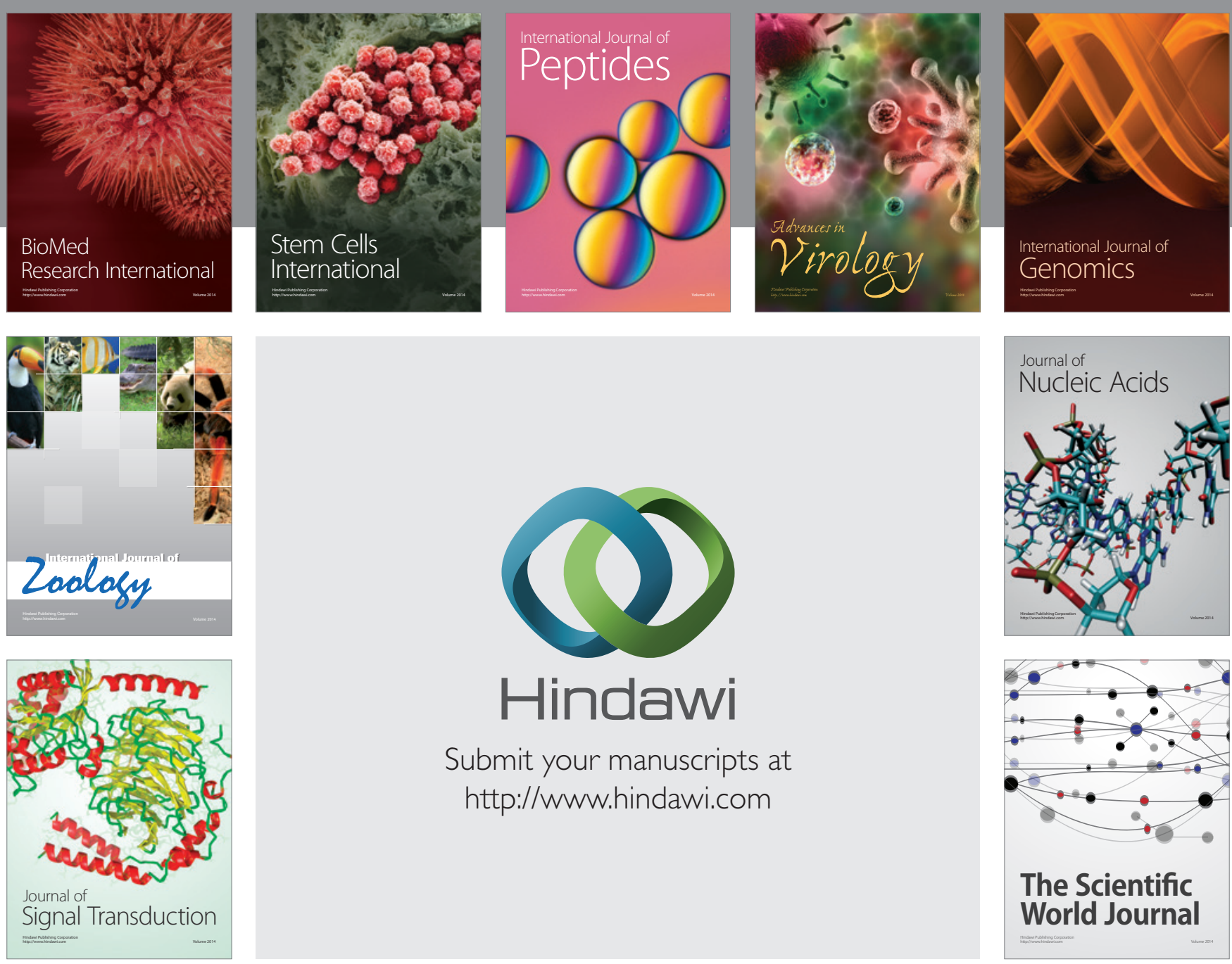

Submit your manuscripts at

http://www.hindawi.com
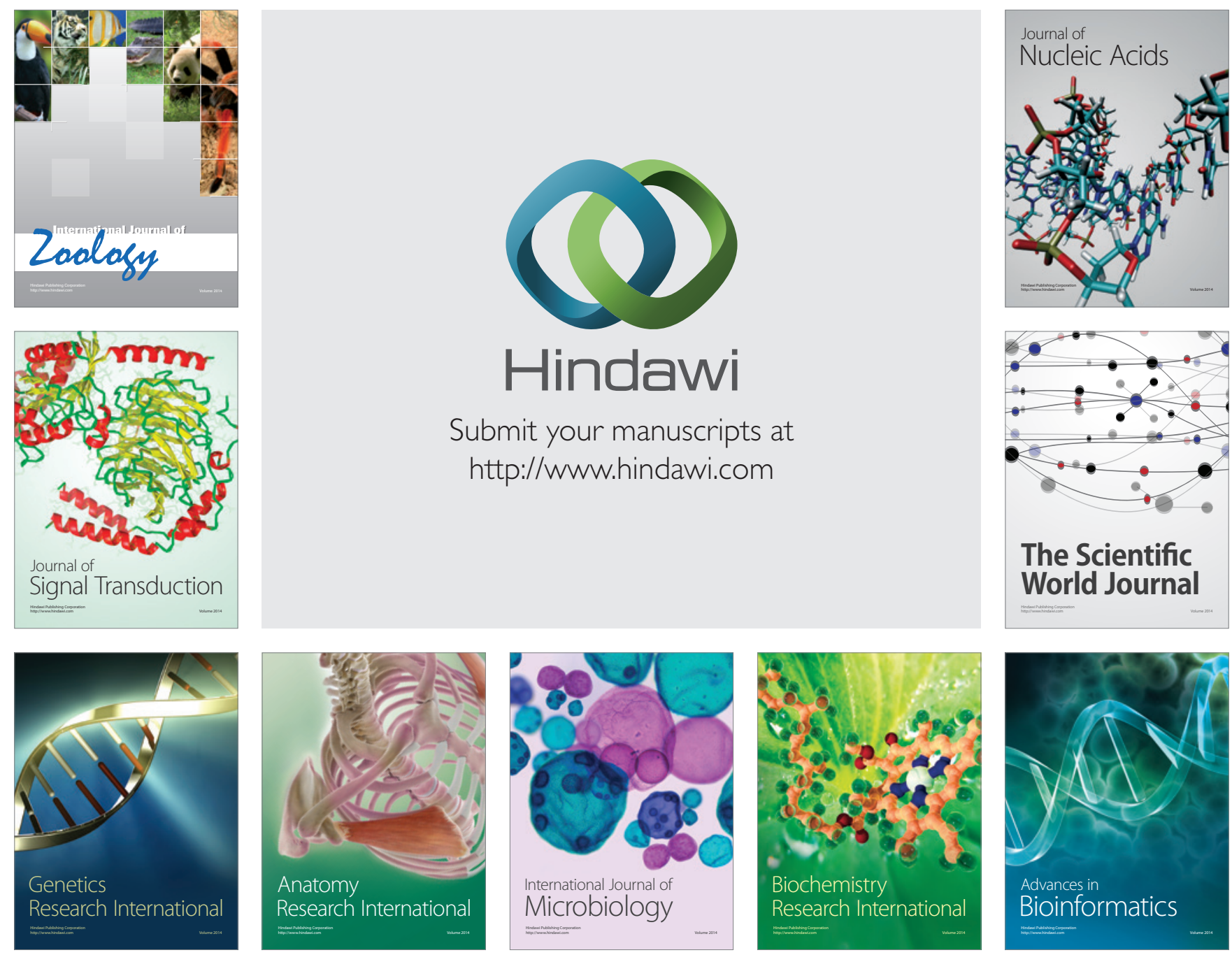

The Scientific World Journal
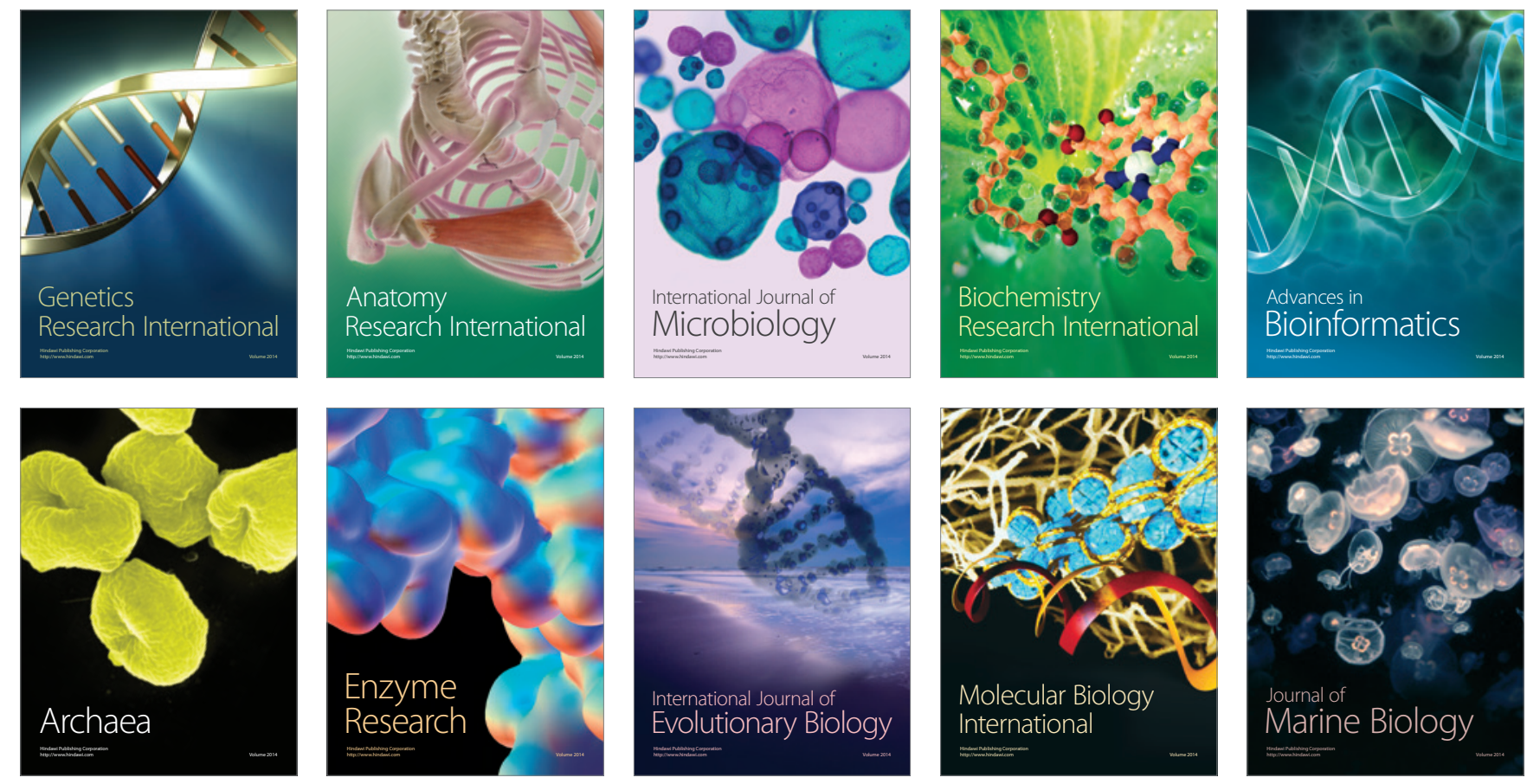